9. Отич О. М. Розвиток творчої індивідуальності студентів професійно-педагогічних навчальних закладів засобами мистецтва : монографія / за наук. ред. І. А. Зязюна. Чернівці : Зелена Буковина, 2011. 248 с.

10. Стратан-Артишкова Т. Б. Творчо-виконавська підготовка майбутніх учителів музичного мистецтва: теорія і практика : монографія. Кіровоград : РВВ КДПУ ім. В. Винниченка. 2014. 440 с.

11. Sugiera Małgorzata. Theatre as Contagion: Making Sense of Communication in Performative Arts. Text Matters, Volume 7, Number 7, 2017 DOI : 10.1515/texmat-2017-0016

12. Fedorenko, S. Methodological potential of the US general education in shaping students' liberal culture. Journal of the $\mathrm{Na}$ tional Technical University of Ukraine "Kyiv Polytechnic Institute": Philology and Educational Studies, 2016, 7, P. 73-78.

\title{
References
}

1. Balme Ch. (2008). Introduction to theatre studies. Lviv : VNTL-Classic [in Ukranian].

2. Goncharenko S.U. (2011). Ukrainian Pedagogical Encyclopedic Dictionary. Rivne : Volyn Oberehy [in Ukranian].

3. Kulka I. (2014). Psychology of art. Kharkiv: Humanist. Center [in Ukranian]. Ukranian].

4. Zyazun I.A. (2012). Existential Peculiarities of Pedagogical Activity. Cherkasy University. Series: Ped. Science [in

5. Lavrinenko O.A. (2013). Pedagogical skills as a dominant component of pedagogical action. The theory and practice of social systems management: philosophy, psychology, pedagogy, sociology. - 2013. - No. 3. - P. 102-106. [in Ukranian].

6. Lymarenko L.I. (2016). General pedagogical bases of activity of the student theater in the system of professional training of future teachers: Doctor's Thesis. Kherson : KSU [in Ukranian].

7. Locareva G.V. (2016). Main factors of the perception of the artistic-information system of the work of art (sociopedagogical aspect). Current problems in the history of the theory and practice of artistic culture: Vip. VI: Sb. sciences Ave at 2 pm. Part 2, 166-179 [in Ukranian].

8. Mozgovy V.L. (2014). The direction of pedagogical action: theoretical and methodical aspects: the monograph. Mykolaiv : Ilion [in Ukranian].

9. Otich O.M. (2011). Development of creative individuality of students of vocational-pedagogical educational institutions by means of art. Chernivtsi : Zelena Bukovina [in Ukranian].

10. Stratan-Artishkova T.B. (2014). Creative and performing training for future teachers of musical art: theory and practice: the monograph. Kirovograd: RVB KDPU named after V. Vynnychenko [in Ukranian].

11. Sugiera M. (2017). Theatre as Contagion: Making Sense of Communication in Performative Arts. Text Matters, Volume 7 , Number 7. doi: 10.1515 / texmat-2017-0016 [in English].

12. Fedorenko, S. (2016, January 17). The methodological potential of the US general education in shaping students' liberal culture. Journal of the National Technical University of Ukraine "Kyiv Polytechnic Institute": Philology and Educational Studies, 7, 73-78 [in Ukranian].

Стаття надійшла до редакції 06.09.2018 p.

UDC 378:008

\author{
Novikova Innola \\ Doctor of Economical Sciences, \\ Associate Professor, \\ Head of the Department of Economics \\ and Management, Institute of Innovative Education \\ of Kyiv National University \\ of Construction and Architecture \\ ORCID 0000-0002-7322-6727 \\ Prusov Dmitry \\ Doctor of Technical Sciences, \\ Associate Professor, Senior Research Fellow, \\ Head of the Department of Territory Management, \\ Institute of Innovative Education of \\ Kyiv National University \\ of Construction and Architecture \\ ORCID 0000-0002-1720-2798
}

\section{CULTUROLOGICAL ASPECT OF HIGHER EDUCATION IN UKRAINE}

The purpose of the article is to identify and substantiate the necessity of humanitarian education in higher education, and to increase the role of culture in the system of higher education. Methodological basis of the research is the use of both general scientific and sociological methods. The theoretical and methodological basis of the article is the system of general scientific and special methods, namely:historical-logical method - to study the evolution of thought regarding the definition of the cultural aspect of education; theoretical generalization - to determine the functions of culture; systematization - to streamline approaches to cultural interpretations in education.General scientific methods of systematization and generalization, the method of comparative analysis allowed to assess the impact of culture on the higher education system. The scientific novelty lies in substantiating the necessity of expanding the cultural aspect of the higher educationsystem, taking into account the current trends in the development of the country's economy and the requirements of society. Conclusions Today, the development of the higher education system of Ukraine takes place against the backdrop of spiritual devastation; for the revival of the cultural component of education today, it is necessary to re-emphasize higher education on the cultural development of the student's personality, the formation of cultural values of his education, the development of not just a literate person, but harmoniously and comprehensively developed, broad-minded, spiritually-cultural enlightened personality. In order to maximize the use of the positive potential of modern trends in the development of education and overcoming their negative

(C) Novikova I., 2019

(C) Prusov D., 2019 
effects necessary, in our opinion, there are a number of activities implemented, in particular:increasing the culturalization of the higher education system, raising the education level of society, decentralization of the higher education system, gradual restructuring and optimization of specialists training with the obligatory involvement of employers in order to bring the higher education system to the real needs of the national economy; development of the education system to long-life learning;increasing attention to the social sciences block of higher education and issues of university self-governance, which largely depends on the future participation of young people in socio-political life;purposeful educational work aimed at informing parents and entrants interested in the public about the value of certain specialties in the domestic and international labor market.

Keywords: humanitarization; culture; higher education; labor market; culturalization of education.

Новикова Іннола Вікторівна, доктор економічних наук, доцент, завідувач кафедри економіки та менеджменту ВСП «Інститут інноваційної освіти Київського національного університету будівництва та архітектури»; Прусов Дмитро Едуардович, доктор технічних наук, старший науковий співробітник, доцент, завідувач кафедри управління територіями ВСП «Інститут інноваційної освіти Київського національного університету будівництва та архітектури»

Культурологічний аспект вищої освіти України

Мета статті - полягає у визначені та обґрунтуванні необхідності гуманітаризації вищої освіти, підвищення ролі культури у системі вищої освіти. Методологічною основою дослідження $є$ використання як загальнонаукових так і соціологічних методів. Теоретичним і методичним підґрунтям роботи $€$ система загальнонаукових і спеціальних методів, а саме: історикологічний метод - для дослідження еволюції економічної думки щодо визначення культурного аспекту освіти; теоретичного узагальнення - для визначення функцій культури; систематизації - для упорядкування підходів до трактувань культури в освіти. Загальнонаукові методи систематизації та узагальнення, метод порівняльного аналізу дозволили здійсни оцінку впливу культури на систему вищої освіти. Наукова новизна полягає в обґрунтуванні необхідності розширення культурологічного аспекту системи вищої освіти з урахуванням сучасних тенденцій розвитку економіки країни та вимог суспільства. Висновки Розвиток системи вищої освіти України сьогодні відбувається на фоні духовної спустошеності, для відродження культурної складової освіти сьогодні необхідно переакцентувати вищу освіту на культурний розвиток особистості студента, формування в нього культурних цінностей освіти, розвитку не просто письменної людини, а гармонійно і всебічно розвиненої, широкомислячої, духовнокультурної освіченої особистості. 3 метою максимального використання позитивного потенціалу сучасних тенденцій у розвитку освіти та подолання їх негативних наслідків необхідною, на наш погляд, $є$ реалізація низки заходів, зокрема: підвищення культуризації системи вищої освіти, підвищення рівня освіти в суспільстві, децентралізація системи вищої освіти, поступова реструктуризація й оптимізація підготовки спеціалістів з обов'язковим залученням роботодавців з метою приведення системи вищої освіти у відповідність до реальних потреб національної економіки; розвиток системи освіти протягом життя; підвищення уваги до суспільствознавчого блоку вищої освіти та питань університетського самоврядування, від чого значною мірою залежить майбутня участь молодих людей у суспільно-політичному житті; цілеспрямована просвітницька робота з метою об'єктивного інформування батьків і абітурієнтів, зацікавленої громадськості щодо цінності тих чи інших спеціальностей на вітчизняному і міжнародному ринку праці.

Ключові слова: гуманітаризація; культура; вища освіта; ринок праці; культуризація освіти.

Новикова Иннола Викторовна, доктор экономических наук, доцент, заведующий кафедрой экономики и менеджмента, ОСП «Институт инновационного образования Киевского национального университета строительства и архитектуры»; Прусов Дмитрий Эдуардович, доктор технических наук, старший научный сотрудник, доцент, заведующий кафедрой управления территориями, ОСП «Институт инновационного образования Киевского национального университета строительства и архитектуры»

Культурологический аспект высшего образования Украины

Цель статьи заключается в определении и обосновании необходимости гуманитаризации высшего образования, повышении роли культуры в системе высшего образования. Методологической основой исследования является использование как общенаучных, так и социологических методов. Теоретической и методической основой работы является система общенаучных и специальных методов, а именно: историко-логический метод - для исследования эволюции мысли по определению культурного аспекта образования; теоретическое обобщение- для определения функций культуры; систематизация- для упорядочения подходов к трактовок культуры в образовании. Общенаучные методы систематизации и обобщения, метод сравнительного анализа позволили провести оценку влияния культуры на систему высшего образования. Научная новизна заключается в обосновании необходимости расширения культурологического аспекта системы высшего образования с учетом современных тенденций развития экономики страны и требований общества. Выводы. Развитие системы высшего образования Украины сегодня происходит на фоне духовной опустошенности, для возрождения культурной составляющей образования сегодня необходимо переакцентировать высшее образование на культурное развитие личности студента, формирование у него культурных ценностей образования, развития не просто грамотного человека, а гармонично и всесторонне развитой, широкомыслящей, духовно-культурной образованной личности. С целью максимального использования позитивного потенциала современных тенденций в развитии образования и преодоления их негативных последствий необходимым, на наш взгляд, является реализация ряда мероприятий, в частности: повышение культуризации системы высшего образования, повышение уровня образования в обществе, децентрализация системы высшего образования, постепенная реструктуризация и оптимизация подготовки специалистов с обязательным привлечением работодателей с целью приведения системы высшего образования в соответствие с реальными потребностями национальной экономики; развитие системы образования в течение жизни; повышение внимания к обществоведческому блоку высшего образования и вопросам университетского самоуправления, от чего во многом зависит будущее участие молодых людей в общественно-политической жизни; целенаправленная просветительская работа с целью объективного информирования родителей и абитуриентов, заинтересованной общественности относительно ценности тех или иных специальностей на отечественном и международном рынке труда.

Ключевые слова: гуманитаризация; культура; высшее образование; рынок труда; культуризации образования.

Formulation of the problem. The polemic that has existed in recent years among high school students about the need for humanitarian education, the increasing role of the cultural aspect of education and the increasing influence of patriotic education, proves the existence of several points of view on this problem. Today's system of higher education in modern conditions, unfortunately, does not fully meet the requirements of time, this is a rather serious problem, since higher education in modern conditions is one of the main factors in the growth of the human capital quality, the generator of new ideas, the key to the dynamic development of the economy and society in as a whole. There is a need to reform the education system, because for Ukrainian higher education the updating should be a priority in order to truly fulfill the important tasks assigned to it taking into account the actual world trends in the development of education in the broad socio-economic context. 
Modernization of higher education in Ukraine requires to overcome a number of problems, among which the following, in our opinion, are relevant: the mismatch of the structure of training specialists to the real needs of the economy, the reduction of the education quality, corruption in the higher education system, separation from the demands of employers, slow pace of integration into European and World intellectual space. But one of the most important problems, which is hardly investigated in the scientific literature, is the humanization of higher education and the need to introduce a cultural dimension into the system of higher education. We consider the cultural aspect not only from the point of view of increasing the students' knowledge about the culture of Ukraine, and its history, but also as an increase in national self-knowledge, patriotic education, improvement of the cultural development of young people, instilling world cultural values, and increasing the possibility of adapting youth to the world's space.

Analysis of recent researches and publications. The negative influence on the development of the system of higher education in recent years is dehumanization of all aspects of society, devaluation of universal values, the substitution of true values by mass culture anti-values, the strengthening of the individualization process, the dominance of market relations, which led to an aggravation of the spiritual crisis of personality. It leads to the fact that some of the youth gradually degrades spiritually and culturally, lose their individuality, the thirst for self-improvement and the development of their own potential. In recent years, education has increasingly been seen as a product of high market value; a means of a promising competitive position in the labor market and only then as a means of gaining knowledge.

That is why today there is an urgent need for the restructuring of higher education to the cultural development of the student's personality, the formation of his cultural values of education. The problem of formation of cultural values in the system of higher education is multidimensional. Theoretical foundations of the study of universal values and certain aspects of studying the spiritual and cultural values of education were developed by domestic and foreign scientists - S. Anisimov, M. Berdyaev, G. Vihlytsov, B. Gershunsky, A. Drobnitsky, A. Zdravomyslov, M. Kagan, A. Losev, M. Mamardashvili, G. Rickert, V. Rosen, V. Tugarinov, M. Scheler et al.; psychologists - B. Ananiev, I. Bech, A. Bodalev, L. Vygotsky, D. Leontiev, A. Leontiev, V.Myasishchev, S. Rubinstein, M. Yannickiy; educators - B. Bim-Bad, E. Bondarevskaya, I. Zyazyun, Yu.Pelech, P. Podkassisty, A. Petrovsky, V. Slastonin and others.

Purpose of the article. The purpose of the paper is to identify and justify the need for humanization of higher education, and to enhance the role of culture in the higher education system.

Presentation of the main research materials. The assessment analysis of the modern system of higher education in Ukraine indicates a significant expansion of the concept of education as such; this tendency has started in Ukraine since the mid-1990s, and includes both an increase in the number of higher educational institutions and a rapid increase in the total number of students and graduates of higher education institutions. We do not think that it is possible to talk about the negative effects of rapid expansion of the higher education system, but this tendency can lead to negative consequences. According to statistics, about $85 \%$ of graduates of Ukrainian secondary schools enter university immediately upon graduation. At the same time, in recent years, the lack of specialists in the labor specialties, in particular in the metallurgical, machine-building, chemical industries, and civil engineering and construction, is particularly acute. The indicated rate of admission of graduates of Ukrainian secondary schools to higher educational institutions is very high by the world standards. For comparison: in 2012, about $66 \%$ of high school graduates entered the university [1]. At the same time, according to another important indicator of the development of the higher education system, namely the share of people with higher education, Ukraine is not among the unconditional leaders.

According to a survey among OECD countries (the Organisation for Economic Co-operation and Development brings together 34 countries of the world, most of them high-income countries and a high human development index), the top ten countries with the highest share of people with higher education are Canada $(51 \%)$, Israel (46\%), Japan (45\%), the United States (42\%), New Zealand (41\%), South Korea (40\%), the United Kingdom (38\%), Finland (38\%), Australia (38\%), Ireland (37\%) [2]. By the sum of the indicators of the shares of persons with full (22.7\%) and incomplete higher education (20.5\%) [3], it can be argued that the actual corresponding indicator for Ukraine is about $35 \%$, given that among the number of persons with incomplete higher education also includes those, who have not received full higher education or will not receive it in the future. According to the international indicator of the level of engagement in higher education (Gross Enrollment Ratio - the percentage of persons receiving higher education, regardless of their age, of the total number of persons, who are typical for higher education), Ukraine occupies one of the leading places among the countries of Central and Eastern Europe (73\%). At the same time, our country in terms of involvement in higher education lags behind countries such as Finland (93\%), the USA (82\%), Sweden (79\%) and Norway (78\%), which also have significantly higher level of total social-economic development [4].

As in many European countries, including Ukraine, higher education has already evolved with a certain privilege on the social standard, the role of higher education in the cultural-educational direction is increasing, this applies not only to the study of the cultural aspects of the history of Ukraine, the development of patriotism, but also to the increase culture of the population, creation of cultural tendencies of youth [5]. Mass high education, despite all its weaknesses and negative consequences, is increasingly becoming a social reality such as writing or access to telephony or the Internet, and therefore it is not necessary to justify 
the need to reduce the system of higher education, and to find mechanisms for its more effective use in the interests of raising the cultural level of the population. Unfortunately, the situation with the mass of higher education leads to the decline in the cultural level of students, education is no longer an elite product for a particular population, so there is a need to increase the cultural component of the higher education system. The most negative effect of the increase in the mass of higher education, in our opinion, is the impairment of the diploma of higher education, the inflation of the qualifications obtained. The more people have higher education diplomas, the more acute is the competition for jobs that require such a diploma. In the absence of growth or reduction of the number of workplaces, qualification requirements naturally increase, which leads to further strengthening of the requirements for educational qualifications and personal qualities of specialists will already be an additional competitive advantage in the labor market. The situation is even more acute in the context of the inadequate link between the structure of training specialists in higher educational institutions and the real needs of the economy, which is an outdated problem of Ukraine. In this regard, the need to align the employers' requirements to the specialists with those that taught at universities is very important.

Today, a significant number of parents and university entrants, both in Ukraine and abroad, give the current higher education the social value inherent to it in the previous era, thus contributing to the further growth of the mass character of higher education, overstating expectations of its results. These high social expectations also have a tendency to inflation: higher education, as a result of masscharacter, is transformed from a preference to a standard that is already not as positive as a negative one - the absence of higher education gives a certain advantage, but a significant disadvantage is its absence. In public opinion there is an idea of the critical need for "professionalism", not necessarily embodied in certain knowledge and skills, but necessarily formally confirmed by the diploma of higher education of the "established standard". Higher education or scientific degree becomes an attribute of social status, the weight of the symbolic (in contrast to the real - specific knowledge, skills and abilities) of the component increases. [6]. That is why the role of culture in the system of higher education increases. To the main cultural values of education we include:

$>$ Human development as an individual;

$>$ Obtaining knowledge and experience, professional skills, competence in all spheres of science;

$>$ The ability to develop spiritually and culturally; education;

The desire to self-development of the individual and the disclosure of his abilities and self-

> Focus on the upbringing of love, respect, compassion, heartfelt, friendly attitude towards people, love for their homeland and traditions;

> Form in young people good manners, honesty, kindness, and ability to behave in society.

An important potential socio-political consequence of mass character of education is the increase in the social expectations of young people, who seeks a better quality of life and, at the same time, ready to make personal efforts in professional activities and take active and responsible participation in the political life of the state and in the processes of its renewal.

Conclusions. Today, the development of the higher education system of Ukraine takes place against the backdrop of spiritual devastation; for the revival of the cultural component of education today, it is necessary to re-emphasize higher education on the cultural development of the student's personality, the formation of cultural values of his education, the development of not just a literate person, but harmoniously and comprehensively developed, broad-minded, spiritually-cultural enlightened personality. In order to maximize the use of the positive potential of modern trends in the development of education and overcoming their negative effects necessary, in our opinion, there are a number of activities implemented, in particular: increasing the culturalization of the higher education system, raising the education level of society, decentralization of the higher education system, gradual restructuring and optimization of specialists training with the obligatory involvement of employers in order to bring the higher education system into the real needs of the national economy; development of the education system to long-life learning; increasing attention to the social sciences block of higher education and issues of university self-governance, which largely depends on the future participation of young people in socio-political life; purposeful educational work aimed at informing parents and entrants interested in the public about the value of certain specialties in the domestic and international labor market.

\section{תimepamypa}

1. College Enrollment and Work Activity of 2012 High School Graduates - US Bureau of Labor Statistics, April 17, 2013 URL: http://www.bls.gov/news.release/hsgec.nr0.htm

2. The Most Educated Countries in the World - Edu-Active.com, 21.09.2013 URL: http://www.eduactive.com/news/2013/sep/21/most-educated-countries-wg2orld.html

3. Рівень освіти населення у відповідних вікових групах - Ukrstat.org - публікація документів Державної Служби Статистики України URL: http://ukrstat.org/uk/operativ/operativ2010/gdn/sdh/dod 06.htm

4. Оксамитна С., Виноградов О., Малиш Л., Марценюк Т. та інші. Молодь України: від освіти до праці/ за ред. С. Оксамитної. К.: ВПЦ НаУКМА, 2010. с. 18.

5. Education at a Glance 2012. OECD indicators. Paris: OECD Publishing, 2012. 360 p.

6. Education at a Glance 2011. OECD indicators. - Paris: OECD Publishing, 2011. $232 \mathrm{p}$ 
7. V. Strauss. Global education market reaches $\$ 4.4$ trillion - and is growing - The Washington Post, February 9,2013 URL: http://www.washingtonpost.com/blogs/answer-sheet/wp/2013/02/09/global-education-market-reaches-4-4-trillion-and-is-growing/

8. Національний інститут стратегічних досліджень "Глобальні тенденції і проблеми розвитку освіти: наслідки для України". Аналітична записка URL: http://www.niss.gov.ua/articles/1537/

\title{
References
}

1. College Enrollment and Work Activity of 2012 High School Graduates (2013) - US Bureau of Labor Statistics, April 17 Retrieved from: http://www.bls.gov/news.release/hsgec.nr0.htm [in English].

2. The Most Educated Countries in the World (2013) - Edu-Active.com, 21.09.2013 Retrieved from: http://www.eduactive.com/news/2013/sep/21/most-educated-countries-wg2orld.html [in English].

3. Level of education of the population in relevant age groups - Ukrstat.org - Publication of documents of the State Statistics Service of Ukraine. Retrieved from: .http://ukrstat.org/uk/operativ/operativ2010/gdn/sdh/dod_06.htm [in Ukrainaian].

4. Oksamytna S., Vinogradov O., Malysh L., Martsenyuk T. (2010) Youth of Ukraine: from education to work - for ed. of Oksamytna S. - Kyiv: VPTs NaUKMA, 18 Ps. [in Ukrainian]

5. Education at a Glance 2012. OECD indicators (2012). Paris: OECD Publishing, - 360 Ps. Retrieved from: http://rb.com.ua/ukr/marketing/tendency/8324/ [in English].

6. Education at a Glance 2011. OECD indicators. (2011)- Paris: OECD Publishing [in English].

7. V. Strauss. Global education market reaches $\$ 4.4$ trillion - and is growing (2013) - The Washington Post, February 9 , Retrieved from: http://www.washingtonpost.com/blogs/answer-sheet/wp/2013/02/09/global-education-market-reaches-4-4-trillion-and-isgrowing/ [in English]. [in English].

8. National Institute for Strategic Studies "Global Trends and Problems of Education Development: Implications for Ukraine". Analytical note [Electronic resource]: Retrieved from: http://www.niss.gov.ua/articles/1537/ [in Ukrainian]

Стаття надійшла до редакції 16.11.2018 p.

Удк 004.773.2

Пелещишин Андрій Миколайович

доктор технічних наук, професор, завідувач кафедри соціальних комунікацій та інформаційної діяльності Національного університету «Львівська Політехніка» ORCID 0000-0002-5022-0410 apele@ridne.net

Добровольська Вікторія Василівна кандидат наук із соціальних комунікацій, доцент, доцент кафедри культурології та інформаційних комунікацій Національної академії керівних кадрів культури і мистецтв ORCID 0000-0002-0927-1179 vika_dobrovolska@ukr.net

Тимовчак-Максимець Оксана Юріївна кандидат технічних наук,

асистент кафедри соціальних комунікацій та інфрормаційної діяльності

Національний університет "Львівська політехніка" ORCID 0000-0002-6044-3407

Oksana.Y.Tymovchak-Maksymets@lpnu.ua

\section{ОСОБЛИВОСТІ СТВОРЕННЯ КУЛЬТУРОЛОГІЧНОГО ДОВІДКОВОГО КОНСОЛІДОВАНОГО ІНФОРМАЦІЙНОГО РЕСУРСУ}

\begin{abstract}
Мета роботи: описати основні принципи пошуку, консолідації та впорядкування довідкової інформації культурологічного спрямування для консолідованого ресурсу та вибрати програмне забезпечення для його реалізації. Методологія дослідження полягає в застосуванні загальнонаукових та спеціальних методів пізнання, зокрема, автор використовував порівняльний та оглядово-аналітичний моніторинг стану сучасних інформаційних технологій створення єдиного консолідованого інформаційного ресурсу для користувачів та методи інтеграції різних документально-комунікаційних комплексів в єдине цілісне електронне середовище. Наукова новизна роботи полягає у здійснення сукупності заходів, які створюють умови для надійного та швидкого отримання користувачами необхідних відомостей. Тому основними задачами культурологічного довідкового консолідованого інформаційного ресурсу є забезпечення пошуку, збирання, аналізу, обробки, зберігання та поширення інформації. Це реалізується шляхом створення й довготривалого зберігання інформаційних ресурсів та їх накопичення у відповідних базах даних, а також розповсюдження відомостей про наявний консолідований інформаційний ресурс через веб-фроруми, групи в соціальних мережах культурологічного спрямування. Висновки. Інтеграція різних інформаційних джерел в єдиному довідковому консолідованому інформаційному ресурсі буде сприяти об'єднанню електронних культурологічних ресурсів в єдину інфор-
\end{abstract}

() Пелещишин А. М., 2019

(ㄱ Добровольська В. В., 2019

() Тимовчак-Максимець О. Ю., 2019 